\title{
THE DYNAMICS OF SUNNI-SHIA RELATIONS IN THE CITY OF A THOUSAND CHURCHES MANADO
}

\author{
Taufani \\ Institut Agama Islam Negeri Manado \\ Jl. Dr. S. H. Sarundajang, Kawasan Ring Road I Manado, 95128 \\ Email: taufani@iain-manado.ac.id
}

\author{
Muh. Natsir \\ Universitas Islam Negeri Alauddin Makassar \\ Jl. Sultan Alauddin No. 63 Gowa \\ Email: siolanatsir@gmail.com \\ Nurman Said \\ Universitas Islam Negeri Alauddin Makassar \\ Jl. Sultan Alauddin No. 63 Gowa \\ Email:nurman.said@uin-alauddin.ac.id \\ Andi Aderus \\ Universitas Islam Negeri Alauddin Makassar \\ Jl. Sultan Alauddin No. 63 Gowa \\ Email: andiaderus@yahoo.com
}

Article received February $12^{\text {th }}, 2021$; Article revised April 11 $1^{\text {th }}, 2021$; Article approved May $8^{\text {th }}, 2021$

\begin{abstract}
This article aims to discuss dynamics of the Sunni and Shia relations in Manado. The data were collected from interviews, observation, and documentation. This study shows that the Sunni and Shia Muslim relations in Manado lived in harmony at the grassroots level. They lived next door, visited, and also helped each other in various matters. However, the relations between Sunni and Shia had been in tension due to anti-Shia campaigns by local Sunni elites and Salafi-Wahabi groups in the public sphere that took advantage of the momentum of the Sunni-Shia conflicts in the country and also the Middle East. They also took advantage of the particular political events deemed to benefit the Shia's existence. Although the Shia groups had become the target of hatred, it did not result in physical violence. The abuse that occurred on the Shia was of verbal and symbolic. This study concludes that the minority status does not always lead to a harmonious relationship within its own internal group.
\end{abstract}

Keywords: anti-shia, shia islam, the muslim minority, sunni and shia relations

\section{INTRODUCTION}

$\mathrm{M}$ anado, a city of a thousand churches, as termed by Makkelo (2010), is a multicultural city located in the land of Minahasa. Although this city has various religions (including sects and denominations), ethnicities, and races, tolerance can be well sustained. Manado has been named the top five cities with the highest tolerance index in Indonesia. Based on the Setara Institute survey, Manado was ranked first in 2017 (Manadokota.go.id, 23 November
2017, accessed on 14 February 2021) and fourth in 2018 (Liputan6.com, 08 December 2018, accessed on 14 February 2021). The issue of tolerance has become a trademark for the local governments in various important events. At the 2019 Manado Fiesta Festival, Mayor Vicky Lumentut said, "Manado always wants to maintain harmony and diversity. We show the values of tolerance from North Sulawesi for Indonesia through the Manado Fiesta Festival" (Mediaindonesia.com, 22 September 2019, accessed on 14 February 2021). 
As a multicultural city, inter-religious relations, especially between Muslims and Christian, run well in settlements, schools and universities, workplaces, and social organizations (Panggabean, 2018). In the religious holiday, baku pasiar (mutual visit) between Muslims and Christian has become commonplace. Baku jaga, safeguarding between Muslims and Christian youth at the takbiran (recitation of praise "God is great" a day before Eid) parade, the Eid prayers, and Christmas has also become an annual routine. These traditions are forms of awareness to sustain the image of Manado as a city of tolerance (Sumampouw, 2015).

The good interreligious harmony in Manado does not necessarily create harmonious relations within Muslims themselves, who are politically and culturally subordinated minority groups. The internal Muslim relations have left the problem of hostility towards the Shia. Since the late 2000s, anti-Shia sentiment has become more intensive in Manado, marked by the strengthening of anti-Shia da'wah in the public sphere through banners, leaflets, lectures, and social media. Several Muslim figures carried out anti-Shia campaigns through sermons at the mosque, Islamic seminars, and takziah (an activity carried out to give condolences and support to the bereft family).

The anti-Shia campaign also spread in the form of 'Shia is not Islam' banners in various corners of the city from 2016 to 2017 , resembling much of the phenomenon occurs in different regions (Halili, 2016). Besides, the anti-Shia campaign in Manado happened quite massive through social media. Lots of netizens widely shared posts about the heresy of Shia teachings. During the massive anti-Shia campaign on social media, there was a phenomenon of religious identity thickening based on sectarianism in the country. Arab spring in the Middle East, which involves Saudi Arabia (Sunni axis) and Iran (Shia axis) and their proxies, have contributed to the escalation of Sunni and Shia conflicts in Indonesia.

This research focuses on the dynamics of Sunni and Shia relations in Manado. Sunni refers to Islamic groups outside Ahmadiyah and Shia. The SalafiWahabi groups are classified as Sunni Islam, although the debate regarding whether it is part of Sunni Islam or not continues up to now (Hasyim, 2019). The term Shia in this study refers to the Twelver Shia, which currently exists in Manado.

This research is necessary because Sunni and Shia relations issue is a prominent religious issue in Indonesia lately. Based on the Wahid Foundation survey in October 2017, the Shia groups were in the 6th position as the most disliked groups in Indonesia with a percentage of 1.2 percent (Tempo.co, 29 January 2018, accessed on 14 February 2020). Manado is selected as the research location because firstly, the research on Sunni and Shia relations in Indonesia generally focuses on Muslim-majority areas. Scholars still rarely come across the research on Sunni-Shia relations in Muslim minority areas. The second, as a predominantly Christian city, Manado has experienced changes in the demographic configuration and the religious landscape where Muslims' number increases day by day. Simultaneously, several religious sects and ideologies also grew and contested to each other due to the climate of openness and democratization in the post-New Order era. The presence of Shia Islam has brought a new nuance to the religious life in Manado.

This article aims to describe the dynamics of Sunni and Shia relations in Manado. This article can enrich the studies related to intrareligious relations and explain the complexity of Sunni-Shia relations in Indonesia. Furthermore, this article can be a mapping source for the government and various stakeholders to prevent potential conflicts from an early time and be an input for the formulation of multicultural based policies.

\section{LITERATURE REVIEW}

The research discussing Sunni and Shia in Indonesia so far has some trends. The first trend focuses on aspects of Shia-Sunni relations, both those concerning harmony and conflict. The second focuses on the Middle East conflict's impact on the Sunni and Shia relations in Indonesia.

Some scholars have portrayed harmonious relations between Sunni and Shia, such as Amaliyah (2015) in Banjaran, Jepara, and Sulaiman (2017) in Bangsri, Jepara. 
Several scholars have portrayed the Shia and Sunni conflicts in Indonesia, such as Syaukani (2009) and Amal (2020) in Bondowoso. Hilmy (2015), Ahnaf et al. (2015), Akmaliah (2015), and Afdillah (2016) focus on the Sunni and Shia conflict in Sampang, Madura. Al Makin (2017) focuses on the persecution of the Shia in Yogyakarta. Izzati (2018) examines the Sunni and Shia conflict in Puger, Jember.

Widyadara (2015) discusses the Sunni and Shia conflicts in Indonesia. She also highlights various cases of violence against Shia in the post-New Order era. Syarif et al. (2017) elaborate on the anti-Shia genealogy, developments, and methods in Indonesia. The scholars who have portrayed the Middle East conflict's impact on Sunni and Shia relations in Indonesia are Sahide (2013) and Humaini (2019).

The research related to Shia in Muslim minority areas in Indonesia is still rarely touched. Amin (2017) has initiated the research on the social history and development of the Shia community in Manado. However, this research has not elaborated profoundly on the issue of Sunni and Shia relations. This research aims to fill the gap by focusing on Sunni and Shia relations in Manado.

\section{RESEARCH METHOD}

In finding out the dynamics of Sunni and Shia relations in Manado, several areas where Shia Muslims live and interact with Sunni Muslims were researched, such as in Tuminting, Singkil, and Kampung Arab. Besides, the Jalan Roda (Jarod), a famous public spot in Manado and a meeting point for Sunni and Shia Muslims in Manado were also researched,

The research was conducted for eight months, from May to December in 2019. An initial research has been previously conducted when facilitating some interfaith forums held in North Sulawesi. From these occasions, some interactions to get to know the Shia Muslim occurred. That interaction further opened much access to conducting observations and interviews and obtaining archives from Shia organizations in Manado.

This research was a field research, employing a phenomenological approach. Phenomenology has two key features. First, there is something essential and meaningful in every human experience. Second, people's experiences must be understood according to the context; thus all views from outside must be embraced to capture the essence of the research subject's experience (Raco, 2010). This research employed the sociology of religion perspective. Sociology of religion by Vrijhof is defined, as quoted by Aziz (2018) "The scientific study ... has the interrelationship and interaction of religion and society as its subject matters". In the sociology of religion, the writers do not search for the right and wrong of a belief but rather dig deeper into a religious phenomenon through an empathic approach.

The data were collected through participant observation, interviews, and documentation. Interactions between Sunni and Shia Muslims in daily life were directly witnessed. people's conversations about Sunni and Shia issues were also noticed. In the interview process, semi-structured interviews were conducted. The researchers made the question lists which were made as a guide, but the interview was quite flexible. Questions were asked and developed with a great flexibility that more profound information was able to extract from the informants.

In selecting the informants, several criteria were applied; sufficient knowledge of the research topic, vast experiences in dealing with Sunni and Shia, and prominence in Muslim leadership. Interviews were conducted to some Sunni leaders such as those from the Indonesian Ulema Council (MUI), Sarekat Islam, and Muhammadiyah. Shia leaders from the Ahlul Bait Indonesia (ABI) and the Indonesian Association of Jamaah Ahul Bait (IJABI) organizations were also interviewed.

Furthermore, the researchers with sufficient knowledge about socio-religious issues in Manado and Muslims at the grassroots level with deep experiences in dealing with Sunni and Shia matters, such as Muslim activists, students, and Muslim citizens were also interviewed. In the interview, the previously known informants were met first, from whom other relevant informants were directed.

Regarding documentation, various photos and archives from the ABI and IJABI organizations, some posts on social media, and 
news in mass and online media along with some photo collections during field research were collected. Besides, a collection of various references from books and research journals was managed to be obtained. In order to examine the data's credibility, a triangulation technique was employed. This research used qualitative data analysis through the interactive model data analysis coined by Miles and Huberman, consisting of data collection, data reduction, data presentation, and conclusion/verification (Satori and Komariah, 2014).

\section{DISCUSSION}

\section{The Dynamics of Sunni and Shia in Manado}

Even though Manado is known as the Christian-majority city, Islam has existed since the 17th and 18th centuries. In Manado, Islam was spread by Nusantara Muslim traders from Ternate, Gorontalo, Java, Sumatra, and South Sulawesi and by Muslim traders from India and Arabia who came to Maluku Island then crossed over to Manado (Lumenta, 1991).

It seems that the early Islam entered in Manado was the Sunni (Syafii) Islam as the general characteristic of early Islam in the archipelago (Ricklefs, 2007). Shia Islam's existence in Indonesia is found in Muslim majority and Muslim minority areas such as in Manado. Historically, it is still challenging to know precisely when Shia Islam started to enter Manado due to limited physical proof. The emergence of Shia Islam in Manado began with Shia ulama's arrival from East Java, namely Habib Husain al-Habsyi and his entourage in Manado in 1984. The purpose of his visit was to meet Kiai Arifin Assagaf and make a pilgrimage to the graves of Kiai Modjo and Habib Abdullah Assagaf in Tondano (Amin, 2017). The presence of Al-Habsyi and his entourage lasted for two weeks. At the moment of gathering, Al-Habsyi taught Kiai Arifin a lot about the importance of loving the Prophet's family or Ahl al-Bait. Therefore, it can be concluded that Kiai Arifin Assagaf is a local Muslim figure who pioneered Shia preaching in Manado after his encounter with Habib Husain al-Habsyi.

Other information said that Kiai Arifin Assagaf learned about Shia in the 1980s from a Shia ulama who came from Solo namely Habib Segaf Al-Jufri, whom he met when visiting Java. Although Kiai Arifin Assagaf had studied Shia teachings for a long time, he just began to practice Shia fiqh in 2005 (Amin, 2017). The early Shia Muslims in Manado did not preach their teachings openly but only spread them among their closest people. Shia Muslims started to preach their teachings to the public after establishing the IJABI organization in 2005. The Shia groups' activity intensified after Ustad Agil Basarewan converted to Shia in 2009.

Before the tensions between Sunnis and Shia Muslims took place in Manado, both groups lived in harmony. They were active in encountering problems at the grassroots level. They lived next door, visited, and helped each other in various matters. Sunni and Shia Muslims had strong cultural ties due to the similarity in ethnicities, like Gorontalo, Bugis/Makassar, Java, Bolaang Mongondow, etc. It was also due to a sense of solidarity as fellow 'outsiders' and minorities subordinated by the majority of Minahasan Christian groups.

Kiai Arifin Assagaf (died in 2015), a prominent Shia leader in Manado, was known as an ulama with a moderate view. Even though Kiai Arifin was a Shia Muslim, he did not show an exclusive attitude. In order to keep brotherhood with fellow Muslims, Kiai Arifin was actively doing Friday and five times prayers from one mosque to another in the area where he lived in Malendeng. He often spent his time chatting with congregations and mosque administrators after the prayer. In supporting Islamic education and strengthen Islamic brotherhood, Kiai Arifin made his house a center of Koran learning for surrounding Muslims and a center of academic discussions for Muslim intellectuals from all backgrounds.

The Sunni and Shia Muslim relations in Manado have worked well at the grassroots. Shia Muslims did not live in particular Shia settlements, nor were they integrated with other Muslims. Shia Muslims could coexist with Sunni Muslims in various areas of Manado. Shia Muslims were involved in intermarriage with Sunni Muslims, and they each gave freedom to practice their beliefs. Asri Rasjid, a chairman of the ABI of North Sulawesi, had a Sunni wife. Asri and his wife each practiced their beliefs with great respect. 
Also, Asri had parents and younger siblings who adhered to Sunni Islam. However, they all still visited, helped in various matters, and respected each other's choices. During the field research, the researchers often heard the conversation among Muslims that said, "So far we can get along with the Christians, so why should we dislike the fellow Muslims who have different sect with us?)".

Sunni and Shia Muslims in Manado each actively participated in community service in the areas where they lived. When the mosque was undergoing renovation, Shia Muslims helped Sunni Muslims in mutual cooperation. The Shia Muslims also often attended birthday and wedding parties from their Sunni Muslim neighbors. They usually sang and partied together. When the flood hit Manado in 2013, Shia Muslims from the IJABI and ABI organizations provided and distributed aid packages at flood-affected areas such as in Tuminting, Singkil, and Kampung Arab. When Sunni Muslim neighbors experienced grief, Shia Muslims often helped to take care of the deceased person and took part in takziah. Sunni Muslims did the same as Shia Muslims do. When Waston Biahimo's wife, a Shia Muslim, died, her Sunni Muslim neighbors helped to take care of the deceased and took her to the funeral. They also participated in takziah held by the Waston family as a form of empathy and consolation.

\section{Picture 1. Shia Groups Distributed Aid Packages to Flood Victims in 2013 (Source: ABI Archives)}

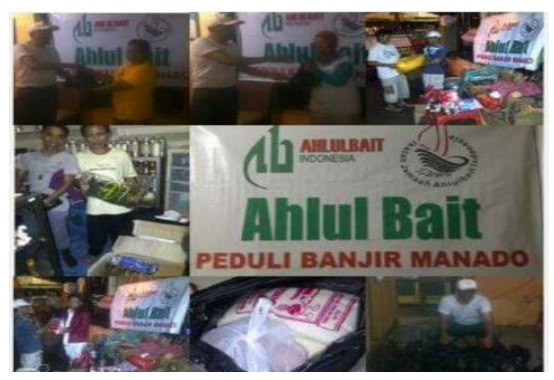

Shia Muslims in Manado did not have particular identities, such as names and clothes that differentiate them from Sunni Muslims. On the other hand, Shia Muslims did not have Husainiyah and Hauzah, the typical assembly point for Shia followers to boost their intellectual and spiritual quality. Some of the Shia Muslims were active in managing mosques and being imams. Aba Awin Halid, Secretary of IJABI Manado, currently served as mosque imam in Sumompo. The mosque congregation did not question the identity of Aba Awin as a Shia. They still entrusted the mosque imam position to Aba Awin because he was considered eligible and sociable. Apart from being the imam, Aba Awin also dedicated himself as a Koran teacher for his neighbors, assisted by his wife, an IAIN Manado graduate. He carried out this activity in his own house.

Alid piety tradition could bring Sunni and Shia Muslims together. Sunni and Shia Muslims often practice several Alid piety traditions in Manado, such as burial pilgrimage before or after Eid al-Fitr, tahlilan (perform rituals to commemorate and pray for the deceased), and maulid (commemoration of the Prophet's birthday). Every month of Rabiul Awal, a born month of the Prophet, Shia Muslims and Sunni Muslims often recited the barzanji (a prayer, praise, and narration of the Prophet Muhammad's history) together. Another tradition that could bring Sunni and Shia Muslims together was the honor of the sayyids and habaib. One of the most respected habaib among Sunni and Shia Muslims in Manado was the late Habib Idrus bin Salim AlJufri (Guru Tua), the founder of Alkhairaat. Guru Tua was an ulama who had contributed to Islamic da'wah and education in North Sulawesi. Several Sunni and Shia Muslims in Manado have received formal education at Madrasah Alkhairaat. As a form of respect for Guru Tua, some Sunni and Shia Muslims put a Guru Tua's picture on their home wall. At Aba Awin's house, the picture of Guru Tua was also there. Aba Awin admitted that he had great respect for Guru Tua because he gained much knowledge and wisdom from the Alkhairaat.

One of the festivities that could br Sunni and Shia Muslims together was Lebaran Ketupat. Historically, the Lebaran Ketupat is a Javanese festivity passed down by Kiai Modjo when he was exiled in Kampung Jawa Tondano (Djojosuroto, 2013). Until now, the Lebaran Ketupat has become an annual festivity that Muslims annually celebrate in Manado, especially those living in Singkil and Tuminting Districts. This festivity is usually held a week after the Eid al-Fitr (seventh day of the month of Shawwal). It is a form of gratitude after performing the fasting of Ramadan and fasting of Shawwal for six 
consecutive days and also as a medium of togetherness among various groups of society.

In the Lebaran Ketupat context, both Sunni and Shia Muslims often became hosts and guests. When attending the Lebaran Ketupat held at Asri Rasjid's house in Wonasa Kapleng, Singkil District, in 2017, several young Muslim and Christian activists and Asri's extended family were met. The guests who were present at that time talked about various topics in a relaxed way. Asri often offered his guests to bring food home (babungkus). For Manadonese, babungkus is a form of hospitality by the host to a guest.

One could see Sunni and Shia Muslims encounter in the Jarod. Jarod is a famous public spot in Manado, where various elements of society meet. Jarod is an open and egalitarian place for discussing a wide range of topics, from trivial to serious talks. Ustad Agil Basarewan (passed away in 2011), one of the leading Shia figures and also a successful businessman in Manado, was known as a loyal visitor to Jarod during his lifetime. Ustad Agil always spent his time coming to Jarod to discuss and chat with activists. Every time he visited Jarod, Ustad Agil frequently treated his discussion partners.

Habib Hasan Mulachela, another Shia figure in Manado, was also an active visitor to Jarod. He always spent his time chilling out with Jarod visitors, some of whom were Sunni Muslims. Many people in Jarod knew that Habib Hasan was a Shia. However, they still showed respect to Habib Hasan due to his warm personality. Many people admitted Habib Hasan's knowledge about Islam. Habib Hasan was a teacher at Alkhairaat and a Koran teacher in Kampung Arab before being a trader.

The conversation about Shia in Manado began to appear to the public in the late 2000s. It was due to a rumor which said that Kiai Arifin was a Shia Muslim. The people knew that the Shia was the teachings that glorified 'Ali> ibn Abi> Tla>lib than the other Prophet's companions. The rumor of Kiai Arifin as a Shia was a conversation topic at various coffee shops. However, Muslims generally did not exaggerate this issue because they still respected Kiai Arifin. Kiai Arifin was accused of being a Shia because he often praised Imam 'Ali> and his descendants when delivering religious sermons. Besides, he always straightened his hands down --as Ja'fari's jurisprudence teaching is a bit different from Shafii's jurisprudence-- when praying in the congregation, thus it strengthened the accusation that he was a Shia.

The anti-Shia sentiment began to spread in the public sphere when the Kampung Arab faction, led by the duo of Gontor alumni, Ustad Abdurrahman Mahrus and Ustad Arya Amir, often discussed Shia heresy in various sermons. The anti-Shia polemics occurred in 2008 in Komo Dalam triggered by Ustad Abdurrahman Mahrus' religious assembly member who did not accept the insults against the Sunni groups in the massacre of Husein (the grandson of the Prophet Muhammad) in Karbala. It then prompted a polemic among the congregation of the mosque in Komo Dalam. In order to clear up the problem, the Nurullah Komo Dalam mosque administrators invited Muzwir Luntajo, a STAIN (now IAIN) Manado lecturer, to give a sermon about the Karbala tragedy. Muzwir, in his speech, emphasized that apart from Sunnis and Shia, Husein was the grandson of the Prophet Muhammad and his murder was a great disgrace to Islam. After giving a sermon, Ustad Abdurrahman Mahrus, Ustad Arya Amir, and their groups finally accused Muzwir of being a Shia.

Furthermore, in some sermons, Ustad Arya Amir often delivered a speech that discouraged the congregation's family from continuing studies at STAIN Manado. Ustad Arya Amir accused STAIN Manado as a center of Shia. He also accused several STAIN lecturers were Shia followers, including Muzwir Luntajo. Muzwir felt shocked by the Shia accusation addressed to him. Muzwir pointed out that the narrative about the Karbala tragedy that he conveyed in his speech was a summary of Sunni Muslim scholars' works, Yusuf Qardhawi and Husain Haikal. Muzwir objected to being accused as a Shia. Muzwir further stated that:

\footnotetext{
"I am a faithful follower of the Alkhairaat. Every time I deliver the sermon, I always mention the names of the four caliphs in my prayer, Sayyidina Abu Bakr wa 'Umar wa Usman wa 'Ali wa 'ala bakirati al-Sahabah wa Tabi'in, so why do you accuse me of being a deviant Shia?)" (Interview with Muzwir on 12 November 2019).
} 
Muzwir then reported Ustad Abdurrahman Mahrus and Ustad Arya Amir on defamation charges. However, Muzwir withdrew his report at the police in 2009 after getting advice from the Alkhairaat leader in Palu, "don't let fellow Muslims fight just because of sect differences" (Interview with Muzwir on 12 November, 2019).

In 2009, Habib Muhsin Bilfagih, a preacher and a grandson of Abdussamad Bachhdar (a well-known ulama from Southeast Minahasa), was accused of being Shia. Ustad Abdurrahman Mahrus accused Habib Muhsin through his various lectures. Before moving to Manado, Habib Muhsin had previously lived in Tarakan and Samarinda. He was a member of the Regional House of Representatives and an NU and MUI administrator in Tarakan. On various occasions, Habib Muhsin always clarified the Shia accusations addressed to him. In an interview, Habib Muhsin stated:

\begin{abstract}
"I am confused why people reject me in Manado? whereas, my relationship with the people in Kalimantan are still going well until now. They all know that I am a real NU proponent "(Interview with Habib Muhsin Bilfagih on 15 November 2019).
\end{abstract}

It can be presumed that the accusation of being Shia towards Habib Muhsin cannot be separated from his popularity as a preacher when he moved to Manado. At the beginning of his arrival in Manado, Habib Muhsin was always invited by government officials, including the Governor of North Sulawesi, Dr. S.H. Sarundajang, to bring religious lectures on various major Islamic holidays. The AlHikam Majelis, which Habib Muhsin built, was always plentifully visited by Muslims from some areas in North Sulawesi.

In 2009, Ustad Agil Basarewan converted to a Shia Muslim. This conversion caused tensions between Sunnis and Shia in Manado. In his early days of conversion, Ustad Agil openly showed the signs of his Shia identity. He delivered the Friday sermon at the Al-Masyhur Mosque, Kampung Arab, about Imam Husain's martyrdom at the hands of fellow Muslims in Karbala. In his sermon, Ustad Agil added the title 'Alaihi al-sala>m (AS) when mentioning Imam Husain's name, a title that is often attached to imams' names whom Shia Muslims honor. At that time, some of the Friday prayer congregation left the mosque because Ustad Agil's sermon was considered too tendentious. During the Friday prayers, Ustad Agil and the Shia Muslims wore black clothes and straightened their hands down during the prayer to show their Shia identity.

After Ustad Agil's conversion to Shia, Ustad Abdurrahman Mahrus and Ustad Arya Amir were very active in carrying out anti-Shia campaigns at various moments of Friday sermons, religious assemblies, and also takziah occasions. Both accused that Shia disbelieved and insulted the Companions (Abu> Bakr, 'Umar, and Usman) and the wife of the Prophet (Aisyah). They also accused that Shia had a different creed from Sunni and only prayed three times. The Shia Quran was different from Sunni, mut'ah marriage was lawful for Shia, Shia defied Ali, Shia had different pillars of faith and Islam, and the doctrine of taqiyyah taught about hypocrisy. In various sermons, Ustad Abdurrahman Mahrus, without hesitation, said that "Shia is more unclean than a dog." Muslims in Manado had finally become familiar with the Shia term. Previously, only particular groups, such as Islamic scholars, academics on Islamic universities, and Islamic mass organization activists, knew this term. With the intensification of the anti-Shia campaign in the public sphere, some Muslims began to draw boundaries based on Sunni and Shia identities. In 2010, a Sunni-Shia dialogue was held at Masjid Al-Masyhur, Kampung Arab, to spread the Shia teachings. In this event Muhammad Baharun an Islamic preacher who had an anti-Shia attitude and was active in promoting anti-Shia sentiment nationally was invited as the speaker. On this occasion, Baharun discussed many classical theology issues, especially Sunni and Shia conceptions regarding leadership and ritual. One of the participants who took part in the event, Kindi Bilfagih, the son of Habib Muhsin Bilfagih, conveyed his criticism in the question and answer session. According to him, the SunniShia dialogue was supposed to invite Shia followers as a speaker to make the discussion more objective (Interview with Iqbal Suma on 07 October 2019).

In 2010, the anti-Shia sentiment was no longer carried out only in religious events. 
It had expanded in the form of leaflets containing Shia figures' names that Muslims should be aware of, such as Kiai Arifin Assagaf, Ustad Agil Basarewan, Habib Muhsin Bilfagih, and others. As a response to the leaflets, Kindi Bilfagih went to Ustad Abdurrahman Mahrus' house to clarify the leaflet contents. However, Abdurrahman Mahrus was not in the place at that time (Interview with Kindi Bilfagih on 15 November 2019). In the same year, Ustad Abdurrahman Mahrus in various sermons always mentioned the names of individuals identified as Shia, including Kiai Arifin Assagaf, Habib Muhsin Bilfagih, Ustad Agil Basarewan, Habib Husen Assagaf, Habib Hasan Mulachela, Ustad Mahmud Lihawa, Waston Biahimo, Muzwir Luntajo, Taher Mongai, Handri Deu, Muhammad Nur Andi Bongkang, Raflin Yusuf, and others (Interview with Habib Hasan Mulachela on 3 September 2019).

During the interview with Habib Hasan Mulachela, he gave the information that he was slandered as funding Shia in Manado with Iranian sponsorship. Habib Hasan was accused of distributing money-which was carried in a bag that he always carried anywhere so people would be interested in converting to Shia. However, the customers of Habib Hasan denied the accusation as slander. According to them, the bag that Habib Hasan often carried did not contain money but used clothes (cabo) and perfume. After that denial, the accusations against Habib Hasan began to disappear from circulation.

In 2012, Muhammad Baharun, the anti-Shia preacher, returned to Manado by the invitation of Ustad Yasir Bahmid, a leading figure of NU Manado. Baharun was invited to talk about the deviations of Shia at the AlMasyhur Mosque, Kampung Arab. In 2013, Ustad Yasir Bahmid again held seminars that discussed the deviations of Shia, which intended to strengthen the Ahl al-Sunnah belief. The activity was held at the Ahmad Yani Grand Mosque with K.H. Idrus Romli, a leading figure of NU Garis Lurus, as a speaker. In 2016, Ustad Yasir Bahmid reinvited Idrus Romli to talk about Shia at the Ahmad Yani Grand Mosque.

By 2013, the anti-Shia campaigns had become even more massive in Manado. The campaigns not only took place on religious occasions but also penetrated the virtual world. Those who carried out the anti-Shia campaigns through social media were ordinary Muslims at the grassroots level. The anti-Shia campaigns between 2008 and 2013 did not occur naturally. There were some factors, both internal and external, behind it. The internal factor was encouraged delegitimize moderate Muslim authorities who have been dominant among Muslims. By doing this, the actors hope to open up access to power and resources in the government and Islamic institutions. Shia labeling to discredit particular Muslims is relevant because the anti-Shia discourse has intensified in the post-New Order era.

The external factor was encouraged by the Sampang conflict involving Sunnis and Shias, which ended with the Sampang Shia leading figure's conviction, Tajul Muluk, as the blasphemy perpetrator against Islam and the expulsion of Shia followers from Sampang. The Sampang conflict has sparked hatred against Shia throughout the country. During the conflict, mass media was intense in reporting the news about this incident.

Prior to the 2014 legislative and presidential elections, an uproar took place in Manado. It was due to the candidacy of a Shiaidentified politician, namely Asri Rasjid. Asri, at that time, was a legislative candidate for the Regional House of Representatives of North Sulawesi Province, representing the Prosperous Justice Party (PKS) with the electoral areas of North Minahasa Regency and Bitung City. Asri's candidacy was interesting because his party, PKS, had been known to have an anti-Shia image (Munandar, 2011; Formichi, 2014; Permata, 2016). The disclosure of Asri's status to the public was originated from the news in various online Islamic media, such as islampos.com, nahimunkar.org, voa-islam.com, and also from the numerous posts by netizens on social media who persuaded the public not to vote for Shia candidates, one of whom was Asri Rasjid from PKS.

After the 2014 elections, the anti-Shia campaign in Manado continued. The actors involved in the campaign were becoming increasingly diverse. Previously, the vigorous actors in carrying out anti-Shia campaigns generally had traditionalist Islamic 
backgrounds, but after 2014, Salafi-Wahabioriented Muslims got involved. The negative campaign theme against Shia expanded. It was no longer solely on theological narrative but had broadened to Shia's political intervention in various Muslim countries. To instill hatred against Shia in society, the Assunnah Manado group, one of the Salafi-Wahabi groups in Manado, frequently posted statuses that discuss Shia teachings' deviations on its social media account. Furthermore, the Assunnah Manado group also usually held public discussions to discuss the danger of Shia.

In November 2016, the Manado Assunnah group conducted a discussion at the Fastabiqul Khairaat Mosque with the theme "Warding the Threat of Radicalism (PKI, Shia, ISIS, and Liberalism) which will Destroy the Unity of the Republic of Indonesia." One of the thematic topics in the discussion was about Shia. It was delivered by a national speaker namely Ustadz Qomar ZA (Head of AsySyariah Magazine). In the discussion, the speaker said that radical groups had surrounded Indonesia from various sides. One of these groups was the Shia. The speaker further stated that the Shia had the teaching of calling for rebellion. In order to support the argument, the speaker conveyed to the participants that, Iran as a country that adhered to the Shia ideology, had conducted political interference in various countries to overthrow the legitimate government and take over power to uphold the doctrine of the wilayatu alFaqi>h. He also accused Iran of supplying weapons to several countries, such as Syria, Yemen, Iraq, and Lebanon. Furthermore, he accused Iran of supporting acts of terror in various countries, including supporting the Shia Houthi group that threw rockets towards the Ka'ba.

In 2016 and 2017, the anti-Shia campaign in Manado took a relatively different form from previous years. At that time, the anti-Shia campaign appeared in 'Shia is not Islam' banners. The banners depicted that the Shia's pillars of faith and Islam were different from Sunni. The banners were found at some corners of the city, such as Komo Dalam Jaga $\mathrm{V}$, Kampung Arab, and Jarod. The option of those places seemingly because they were close to the city center. They are also the Muslim enclaves. The banners aim to bring the message that Muslims must be aware of the dangers of Shia.

The presence of 'Shia is not Islam' banners in some places in Manado is interesting because the public sphere in Manado has been an arena for producing symbolic tolerance discourses so far (Sumampouw, 2019). It has become commonplace that before Eid al-Fitr and Christmas, Muslims and Christians often put up banners congratulating each other in various corners of the city. The annual debate regarding the prohibition of Christmas greetings for Muslims is not Muslim's main attention in Manado. Merry Christmas banners are easy to find in various places, including in the mosque area. In the intra-Muslims tolerance context, Muslims who have minority status have not optimized the public sphere to produce symbolic tolerance discourses as Muslims and Christians. Muslims in Manado were inclined to support the anti-Shia sentiment occurring nationally, marked by the massive banner of 'Shia is not Islam' in various cities in Indonesia.

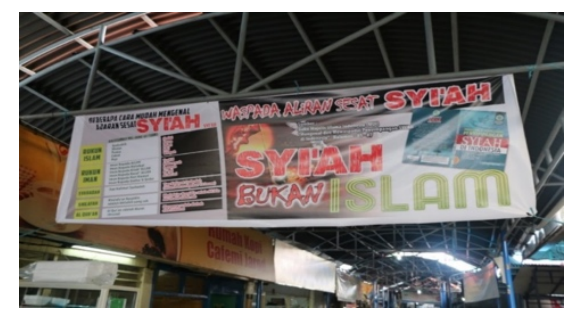

Picture 2. 'Shia is not Islam' banner in Jarod (Source: Personal Photo Collection)

The anti-Shia campaigns in 2014 and after did not happen naturally. There were some factors, both internal and external, behind it. Internal factor is encouraged by the intensification of Salafi-Wahabi groups in Manado, who are notorious for their anti-Shia attitudes and views. Shia, in their eyes, is a group that deviates from the Islamic faith, performs bid'ah (non-Islamic innovations), and promotes hatred against the Companions of the Prophet (Maher, 2016).

External factors are encouraged by the first, the presence of a particular political events considered to benefit Shia's existence. The actors who have anti-Shia tendencies take advantage of this momentum to carry out propaganda to not support Shia politicians with a Shia identity and politicians who are lenient to Shia. Second, the conservative Islamic 
online media play a pivotal role in carrying out the anti-Shia campaign. They have sparked Shia-related talks on social media. According to the BBC Indonesia, in 2015, the period from January to October, the hashtag \#antiSyiah reached more than 39,000 times. It went far beyond the use of the hashtag in 2013, whose numbered only in the hundreds. The word 'Shia' itself in 2015 was tweeted by netizens 530,000 times (Rais, 2015).

Finally, the influence of the Arab Spring in the Middle East involves the Sunni axis (Saudi Arabia) and the Shia axis (Iran) and their supporters. It is undeniable that the tensions between Sunnis and Shia in various cities in Indonesia were strongly influenced by the Arab Spring that hit Yemen and Syria. When the conflict in Yemen and Syria arose, the internet and social media were inundated with information that discredits the Shia regimes in Yemen and Syria as ruthless and despotic.

Although the anti-Shia campaign had existed in Manado, it did not end in physical violence as happened in Jember, Batang, Bondowoso, Sampang, and Yogyakarta Yogyakarta (Syaukani, 2009; Tim Peneliti Nusantara, 2014; Ahnaf et al., 2015; Akmaliah, 2015; Hilmy, 2015; Afdillah, 2016; Izzati, 2018; Amal, 2020). The violence against Shia in Manado was of only verbal and symbolic. Several reasons can explain it. First, the religious issue that becomes the main concern among Muslims in Manado is not about sectarianism but rather relations with Christians (referring to the Minahasan Christian groups as the majority). Muslims feel that they are always mistreated, especially in power-distribution and access to the building of worship houses. In terms of powerdistribution, Muslims never receive adequate representation in government, even though they occupy the second largest position after Christians. Muslims only get the Head of Regional Office of the Ministry of Religious Affairs in the top position, whereas Christians almost rule all sectors of government sectors (Syuhudi, 2019). Furthermore, Muslim also often have the difficulty if they want to build mosque. (Syuhudi, 2017; Komnas HAM RI, 2016).

On the other hand, Christian groups worry about increasing of Muslim numbers in
Manado. Minahasa Christian groups always claim themselves as 'indigenous people,' while they often call Muslims as 'outsiders'). Christians consider Muslims as a potential threat to their status quo (Syuhudi, 2019).

Second, the mainstream Islamic organizations in Manado are inclined to take a moderate stance regarding Islamic sectarianism. Through that way, they do not trigger polemics among Muslims.

Third, the anti-Shia movement in Manado does not have sufficient strength because the actors do not have strong and militant alliances. They also do not have broad support from Sunni Muslims. On the other hand, the groups that often persecute Shia in other cities, such as the Islamic Defenders Front (FPI) and the National Anti-Shia Alliance (ANNAS), do not exist in Manado.

\section{CLOSING}

The presence of Shia Islam in Manado has created a dynamic in the internal relations of Muslims. Based on this research, there are several patterns of relationship between Sunnis and Shia. First, it is cooperative. Sunni and Shia Muslims at the grassroots level live in cooperation, accept differences, and nurture encounters. Second, it is integrated. Sunni and Shia Muslims dissolve differences through intersectarian marriage and the practice of Alid piety. Third, it is of contravention. Muslims do not fully accept the presence of Shia Islam in Manado. The rejection against Shia is then channeled in agitation and hate speech in the public sphere.

This research shows that the image of Manado as a peaceful and tolerant city turns out to be fragile because it has two potential threats; the conflict between Muslims and Christian as a minority and the majority and also the conflict between Sunnis and Shia as a minority and double minority. However, the Muslims and Christian conflict are more likely to end in physical violence than the Sunni and Shia conflict. The former is more vulnerable than the latter because mutual suspicion between Muslims and Christian has been deeply ingrained. Regarding Shia's presence in Manado, Sunni Muslims generally do not consider Shia's existence crucial. The rejection of the Shia is only the work of a few 
individuals without wide support from Sunni Muslims.

This research also shows that Muslims' status as politically and culturally subordinated minority group does not automatically create solidarity and solidity among adherents. Some certain actors have sought to exploit the minority status inherent in Muslims to win their religious interpretation and subordinate other interpretations through cultural antagonism. The actors take an antagonist attitude towards Shia because it can provide publicity and become a way to delegitimize moderate Muslims influence that have been dominant among Muslims. The antagonistic attitude towards Shia is more rational than against Christian because the Shia groups do not have the significant power and influence as the majority Christian groups.

\section{ACKNOWLEDGEMENTS}

The writers would like to thank the supervisors who guided me in this research. The writers also thank the editorial board of the Al-Qalam Journal for publishing this article.

\section{REFERENCES}

Afdillah, Muhammad. 2016. Dari Masjid Ke Panggung Politik: Melacak Akar-Akar Kekerasan Agama Antara Komunitas Sunni Dan Syiah Di Sampang Jawa Timur. Yogyakarta: CRCS UGM.

Ahnaf, Mohammad Iqbal, Samsul Maarif, Budi Asyhari Afwan, and Muhammad Afdillah. 2015. "Pilkada dan Kekerasan Anti-Syiah Di Sampang." In Politik Lokal Dan Konflik Keagamaan: Pilkada Dan Struktur Kesempatan Politik Dalam Konflik Keagamaan Di Sampang, Bekasi, \& Kupang, eds. Mohammad Iqbal Ahnaf and Linah K.Pary. Yogyakarta: CRCS, 17-33.

Akmaliah, Wahyudi. 2015. "Kekerasan Dan Pengusiran Atas Nama Agama Pasca Rejim Orde Baru: Studi Kasus Konflik Syiah Sampang." Jurnal Maarif 10(2, Desember 2015): 222-42.

Amal, M Khusna. 2020. "Anti-Shia Mass Mobilization in Indonesia's Democracy: Godly Alliance, Militant Groups and the Politics of Exclusion." IJIMS: Indonesian Journal of Islam and
Muslim Societies 10(1, June 2020): 2548.

Amaliyah, Efa Ida. 2015. "Harmoni Di Banjaran: Interaksi Sunni-Syiah." Harmoni: Jurnal Multikultural \& Multireligius 14(2, Mei-Agustus 2015): 81-96.

Amin, Ali. 2017. "Revitalisasi Agama Di Sulut (Kasus Studi Kelompok Aliran Syiah Di Manado)." Jurnal Potret: Jurnal Penelitian dan Pemikiran Islam 21(2, Juli-Desember 2017): 44-58.

Aziz, Abdul. 2018. Sosiologi Agama. Yogyakarta: LKIS.

Djojosuroto, Kinayati. 2013. "Ikon Tradisi Ba'do Katupat Sebagai Refleksi Kebudayaan Masyarakat Jaton Di Sulawesi Utara." el Harakah 15(2): 217-27.

Formichi, Chiara. 2014. "Shaping Shi'a Identities in Contemporary Indonesia between Local Tradition and Foreign Orthodoxy." Die Welt Des Islams 54: 212-36.

Halili. 2016. Politik Harapan Minim Pembuktian: Laporan Kondisi Kebebasan Beragama/ Berkeyakinan Di Indonesia 2015. Jakarta: Pustaka Masyarakat Setara.

Hasyim, Arrazy. 2019. Teologi Muslim Puritan: Genealogi Dan Ajaran Salafi. Banten: Yayasan Wakaf Darus-Sunnah.

Hilmy, Masdar. 2015. "The Political Economy of Sunni-Shi'ah Conflict in Sampang Madura." Al-Jami'ah: Journal of Islamic Studies 53(1): 27-51.

Humaini. 2019. "Konflik Sunni-Syiah Di Timur Tengah Perspektif Geopolitik Dan Dampaknya Terhadap Hubungan Sunni-Syiah Di Indonesia." Jurnal CMES XII(2, Juli-Desember 2019): 156-69.

Izzati, Arini Robbi. 2018. "Konflik Agama Antara 'Sunni-Syiah' Di Kecamatan Puger, Kabupaten Jember." In Optimalisasi Peran FKUB Mewujudkan Indonesia Damai, eds. Eko Riyadi and Despan Heryansyah. Yogyakarta: PUSHAM UII Yogyakarta, 71-105.

Komnas HAM RI. 2016. Laporan Tahunan Kebebasan Beragama Dan Berkeyakinan 2016. 
Liput an6.com. 2018. "9 Daftar Kota Toleransi Tertinggi Dan Terendah Versi Setara Institute."

Lumenta, Noldy Oscar. 1991. "Proses Islamisasi Di Manado Pada Abad Ke-17 Dan Abad Ke-18." Universitas Gadjah Mada.

Maher, Shiraz. 2016. Salafi-Jihadism: The History of an Idea. New York: Oxford University Press.

Makin, Al. 2017. "Homogenizing Indonesian Islam: Persecution of the Shia Group in Yogyakarta." Studia Islamika 24(1): 132.

Makkelo, Ilham Daeng. 2010. Kota Seribu Gereja: Dinamika Keagamaan Dan Pengembangan Ruang Di Kota Manado. Yogyakarta: Penerbit Ombak.

Manadokota.go.id. 2017. "Kota Manado Ditetapkan Sebagai Kota Paling Toleran Di Indonesia."

Mediaindonesia.com. 2019. "Manado Merayakan Toleransi."

Munandar, Arief. 2011. "Antara Jemaah Dan Partai Politik: Dinamika Habitus Kader Part ai Keadilan Sejahtera (PKS) Dalam Arena Politik Indonesia Pasca Pemilu 2004.” Universitas Indonesia.

Panggabean, Samsu Rizal. 2018. Konflik Dan Perdamaian Etnis Di Indonesia. Jakarta: PT Pustaka Alvabet dan Pusad Paramadina.

Permata, Ahmad Norma. 2016. "A Study of the Internal Dynamics of the Prosperous Justice Party and Jamaah Tarbiyah." In Islam, Politics and Change: The Indonesian Experience after the Fall of Suharto, eds. Kees van Dijk and Nico J/G. Kaptein. Leiden University Press, 29-78.

Raco, J. R. 2010. Metode Penelitian Kualitatif: Jenis, Karakteristik, Dan Keunggulannya. Jakarta: PT Grasindo.

Rais, Ahmad Imam Mujadid. 2015. "Syiah, Sektarianisme, Dan Geopolitik: Suatu Pengantar." Jurnal Maarif 10(2, Desember 2015): 4-13.

Ricklefs. M. C. 2007. "Sejarah Indonesia Modern: 1200-2004.": 55.

Sahide, Ahmad. 2013. "Konflik Syi'ah-Sunni Pasca- The Arab Spring." Kawistara 3(3, Desember 2013): 314-24.
Satori, Djam'an, and Aan Komariah. 2014. Metodologi Penelitian Kualitatif. Bandung: Penerbit Alfabeta.

Sulaiman. 2017. "Relasi Sunni - Syiah : Refleksi Kerukunan Umat Beragama Di Bangsri Kabupaten Jepara.” Panangkaran: Jurnal Penelitian Agama dan Masyarakat 1(1, Januari-Juni 2017): 19-36.

Sumampouw, Nono S. A. 2015. Menjadi Manado: Torang Samua Basudara, Sabla Aer, Dan Pembentukan Identitas Sosial. Ypgyakarta: Gadjah Mada University Press.

Sumampouw, Nono S.A. 2019. "Menggemakan Perjumpaan: Memanfaatkan Ruang Publik Sebagai Arena Sosialisasi Wacana Kerukunan." Mimikri 5(2): 207-15.

Syarif, Dede, Iskandar Zulkarnain, and Dicky Sofjan. 2017. "Anti Shi'ism in Indonesia: Genealogy, Development, and Methods." Harmoni: Jurnal Multikultural \& Multireligius 16(1, Januari-Juni 2017): 24-37.

Syaukani, Imam. 2009. "Konflik Sunni-Syiah Di Bondowoso." Harmoni: Jurnal Multikultural \& Multireligius VIII(31, Juli-September 2009): 81-102.

Syuhudi, Muh. Irfan. 2019. "Minahasa Dan Politisasi Identitas." In Kekuasaan, Agama, Dan Identitas: Potret Gerakan Politik Lokal Di Indonesia Timur, ed. Wahyuddin Halim. Yogyakarta: Lintas Nalar.

Syuhudi, Muhammad Irfan. 2017. "Perubahan Relasi Antarumat Beragama Di Manado (Kasus Pendirian Rumah Ibadat Pasca PBM 2006).” Jurnal Pusaka 5(1): 23-34.

Tempo.co. 2018. "Survei Wahid Foundation: Komunis Dan LGBT Paling Tak Disukai."

Tim Peneliti Nusantara. 2014. Studi Komparatif Buku: Mengenal \& Mewaspadai Penyimpangan Syiah Di Indonesia. Jakarta Selatan: Penerbiti Titisan.

Widyadara, Resta Tri. 2015. "Konflik SunniSyiah Di Indonesia." Religi XI(2, Juli 2015): 109-24. 